\title{
Hermeneutical Resemblance in Rudolf Bultmann and Thich Nhat Hanh
}

\author{
Joel (J.T.) Young \\ PhD Candidate, Theology, Global Center for Advanced Studies: College Dublin, Dublin, IE, jtyoung@gcas.ie
}

\begin{abstract}
Over the last several decades, academic theology in America has seen a resurgence of interest in the $20^{\text {th }}$ century German-speaking theological movement known as "dialectical theology." While primarily focusing on the theology of Swiss Reformed theologian, Karl Barth, there has also been a revival of curiosity in Barth's academic rival, Rudolf Bultmann, who cultivated the controversial program of "demythologization." Though the recovery of Bultmann's work in English-speaking circles is historically valuable to our understanding of how modern theology progressed, the question still stands as to how it might aid our dialogue in an increasingly pluralistic world. Unpacking one such opportunity is the aim of this paper. Through dialogue with the Zen Buddhism of Thich Nhat Hanh, I show how different contours of Bultmann's thought can aid us in understanding and approaching interreligious discourse through hermeneutical consistencies and resemblance. While this paper discusses several different aspects of Bultmann's and Nhat Hanh's religious thought, the consistencies and resemblance between the two individual thinkers are, no doubt, emblematic of greater Familienähnlichkeit between their respective faith traditions - a topic to be taken up at a later time.
\end{abstract}

KEYWORDS: Rudolf Bultmann, Thich Nhat Hanh, Demythologization, Zen Buddhism, Christianity, Dialectical Theology, Hermeneutics, Interreligious Dialogue

\section{Introduction}

Academic theology in America has seen a resurgence of interest in the 20th century Germanspeaking theological movement, "dialectical theology", for the last several decades. This was caused, in large part, by the influx of noted Karl Barth scholars present in American academies and institutions, viz. Hans Frei (1956), Robert Jenson (1963), George Hunsinger (1991), Bruce McCormack (1997) et al. Alongside this continual unfurling of Barth's legacy in America, not many others from the 20th century dialectical theology movement have received much notice, the least of these being biblical scholar and theologian (and Barth's academic rival) Rudolf Bultmann.

Until recently, Bultmann's theology in America was effectively considered dead-on-arrival. And, for that matter, the scant number of academic engagements with Bultmann typically aimed at continued disagreement. However, Bultmann's theology has seen a revival of curiosity in American academic circles in recent years, due largely to the publication of David Congdon's The Mission of Demythologizing: Rudolf Bultmann's Dialectical Theology (Congdon 2015a). In this work, Congdon looks to overturn two generations of scholarship on Bultmann's hermeneutical program, arguing that Barth, not Bultmann, was the one who went awry from the Dialectical School. Contrary to popular opinion, Congdon claims that Bultmann is the one who faithfully carried dialectical theology through to completion, not Barth.

In any case, the resurrection of Bultmann's work in the academy posits the question of how we can incorporate his program into the modern world. In this paper, I argue that Bultmann can aid us in interreligious dialogue by helping us expose hermeneutical consistencies and resemblance between religious traditions. The extra-Christian tradition I approach here is that of Zen Buddhism, particularly as it is found in the writings of Vietnamese Buddhist Thich Nhat Hanh. The work of Nhat Hanh is a natural starting place for such interreligious dialogue, as Nhat Hanh has written extensively on the teachings of Jesus vis-à-vis the teachings of the Buddha.

I do as much in three parts. First, I outline Bultmann's hermeneutical program of demythologizing, particularly three key elements which find parallels in the Buddhist thought of Thich Nhat Hanh: myth, kerygma, and nonobjectifiability. Second, I do similarly with the work of Nhat Hanh as I do with Bultmann, outlining three particular elements of his thought, viz. interbeing, engaged Buddhism, and nontheism. Last, I bring Bultmann and Nhat Hanh together, arguing for the 
one-to-one hermeneutical resemblance which can be found between them, using the three components of thought from each, discussed in the sections prior, as merely a sample of the broader elements of Familienähnlichkeit which surely exist, both among the thought of the individual thinkers and their respective faith traditions, yet remain to be exposed.

\title{
Bultmannian Hermeneutics and Entmythologisierung
}

In 1941, Rudolf Bultmann published his essay "New Testament and Mythology", which brings us our first exposure to Bultmann's infamous program of entymythologisierung or "demythologization". This program finds its root in the breakdown of ancient cosmology, viz. a geocentric, three-tiered universe with heaven above and hell below, etc. To be sure, though, demythologization is not merely the stripping away of the pre-scientific husk from the New Testament. It also begs the reinterpretation of such ancient theological motifs as redemption, eschatology, pre-existence, et al. Bultmann's claims regarding as much are worth quoting at length:

\begin{abstract}
All of this is mythological talk, and the individual motifs may be easily traced to the contemporary mythology of Jewish apocalypticism and of the Gnostic myth of redemption. Insofar as it is mythological talk it is incredible to men and women today because for them the mythical world picture is a thing of the past. Therefore, contemporary Christian proclamation is faced with the question whether, when it demands with from men and women, it expects them to acknowledge this mythical world picture of the past. If this is impossible, it then has to face the question whether the New Testament proclamation has a truth that is independent of the mythical world picture, in which case it would be the task of theology to demythologize the Christian proclamation (Bultmann 1984, 2-3).
\end{abstract}

Though Bultmann formalized this work in an academic sense, he actually claims that this work began in the generation of disciples immediately following the death of Jesus. This reworking of the faith to fit the current landscape began when the long-awaited parousia never occurred, "partially with Paul, and radically with John" (Bultmann 1958, 32). Bultmann continues, "The decisive step was taken when Paul declared that the turning point from the old world to the new was not a matter of the future but did take place in the coming of Jesus Christ," and "After Paul, John demythologized [sic] in a radical manner...For John the resurrection of Jesus, Pentecost, and the parousia of Jesus are one and the same event" (Bultmann 1958, 32-33).

This explanation of Bultmann's "demythologization" requires a definition of three key components: 1) What exactly is myth? 2) What is the thing concealed under the cover of myth? and 3) How are we to understand a god that has been demythologized? In order to answer the second two questions, we must first address the definition and parameters of myth.

As mentioned above, though myth can be identified with primitive science, it cannot be identified with primitive science as such; primitive-scientific understandings of the world fall within the parameters of myth, but it also extends beyond this. For Bultmann $(1958,19)$, "Myths express the knowledge that man [sic] is not master of the world and of his life, that the world within which he lives is full of riddles and mysteries and that human life also is full of riddles and mysteries."

So, according to Bultmann, myth was a way humanity spoke of itself, reflecting the full battery of human emotions and experiences, i.e. joys, fears, anxiety, hope, etc., in order to translate those emotions and feelings into a cohesive world picture (DE: weltbilt). The key, however, is to acknowledge that myth is no longer an appropriate mode of understanding the world or the self. David Congdon (2015b, 108).comments on the category of myth, saying "Bultmann does not say that myth is false or that it is antithetical to faith; he says, in effect, that it is culturally foreign. Myth belongs to an alien time and place."

For Bultmann, myth is not, like science, objective; it is subjective. It is existentially inclined insofar as one cannot abstract oneself from the myth, but rather one is always a part of it, being 
directly affected by it. With Congdon (2015b, 106), "Unlike science, which seems to understand the totality of the cosmos, myth is "concerned with the grasping of what is individual and particular, what is meaningful for existence here and now." Because of this nature of myth which Bultmann points to here, Bultmann claimed that myth was a fitting vehicle for divine revelation. However, if divine revelation is not defined by or conflated with myth, then what is it?

To answer this question, we have to explain Bultmann's notion and use of kerygma. The word, taken from the Greek New Testament's ки́ between proclamation, revelation, and salvation in early Christianity" (Congdon 2015b, 71). What exactly the kerygma is the task of theology. However, it appears that, according to Bultmann, the kerygma of the Christian faith is a post-Easter phenomenon. This is so because there is a distinction between the message of Jesus and the message of Jesus. Put another way, there is a distinction between Jesus' apocalyptic message and the message of Jesus Christ crucified and resurrected as such. Bultmann $(1955,33)$ says it this way: "he who formerly had been the bearer of the message was drawn into it and became its essential content. The proclaimer became the proclaimed." The kerygma of the crucified and risen Christ is always, for Bultmann, a personal and direct address of the word of God to the hearer. The hearer experienced the content of the kerygma in the form of "dogmas" such as "Jesus is Lord", et al. James F. Kay, in his excellent book on Bultmann's Christology, is worth quoting at length here:

Bultmann regards the dogmatic content of the kerygma as subordinate to the kerygma's function of direct address. In Bultmann's view, the kerygma demands "obedience to" or "faith in" and not - in the first instance — "discussion of." Therefore, when Bultmann speaks of "the kerygma," he typically means the Christian message of God's act in Christ. Granted that Paul formulates this message in theological statements, the vital point for Bultmann is that the message is proclaimed as a summons to decision (Kay 1994, 49).

The kerygma thus comes upon person in an event of faith; an event in which one must choose whether or not they will turn away from the old person and put on the new person. This event of faith is paradoxically both the faith we possess and must renew day-by-day, moment-by-moment, and also the faith that we never possess, but is given as a gift by God When we encounter God in the proclaimed word of the crucified and risen Christ. This faith which we identify paradoxically as both a historical event and a divine event is representative of the last principle of dialectical theology we will discuss here: nonobjectifiability.

At its most basic level, the nonobjectifiability of God is contingent upon the notion that "God is not an entity in the ontological inventory" (Hardwick 1996, 69). This is in line with the Dialectical School's christological emphasis, asserting that, as Christians, knowledge of God cannot be gleaned from any other source but the Christ event. Put another way, asserting God's nonobjectifiability is the most absolute and antithetical defense to natural theology; if God is not an entity in the ontological inventory, but is absolutely transcendent and wholly other, we can rule out pantheism, panentheism, monism, etc. en masse, along with the notion, derived from ancient cosmology (yet still circulating in various forms today), that God is some mythical construct in the sky.

Nonobjectifiability is the radical claim that God is never something at our disposal to intellectually grasp onto, manipulate or control. Rather, God and God's revelation via the Christ event is only available to us through faith alone. With Congdon (2015b, 52), "To say that God is nonobjectifiable is a way of saying that God cannot be known according to the flesh". And if God cannot be objectified, but can only be identified paradoxically through the lens of faith, then we must conclude that looking to the Jesus of the bible tells us nothing of God.

Rather, our only source of divine revelation is the event of encounter we have with the risen Jesus through the proclamation of God's word. This event of encounter, thrust upon the human being caught in the trajectory of the proclamation of God's word, means that we can only ever speak of what God does, not what God is in Godself; to do as much would be to objectify God, therefore 
making God a part of the ontological inventory. Congdon (2015b, 65).says this extremely well: "[Paradoxical identity] argues that God acts in history, but in a way that is accessible only to faith. Theology without objectification thus speaks of God's revelatory action in history as an event that truly happens but that never becomes an observable part of the world. It is an event that must happen again and again, which we can never prove but can only proclaim anew."

A short case study may be in order here to show how such an abstract concept often ends up working out in the lives of people-of-faith: Before going to seminary, I was a member of an evangelical-nondenominational church down the road from where I attended university in Missouri. One night, during the worship service, a particularly bad storm came through the city, triggering the tornado sirens. Being in the Midwest where tornadoes are relatively commonplace in the warm months, this frightened many people. So, the pastor stopped the service and prayed aloud with the congregation for the safety of the church and the city, recalling the stories of God stilling storms in the bible. Midway through the prayer, the tornado sirens ceased to wail and it was believed that, due to the prayers of the congregation, God rebuked the storm.

There are rational and natural reasons why the sirens might have snapped off at that very moment, whether it be because the weather service believed a tornado was no longer a possibility, or because the timer they were set on happened to go off at that moment. However, those who were present and active in the faithful act of prayer identify it with a divine event in which God was indeed at work in the world. This can never be verified or proved; it's nothing that could ever be observable to the world or anyone outside the lens of faith, and yet, those praying found meaning and order in the event due to their belief that God heard their prayers and answered them. This is an example of how paradoxical identity and nonobjectifiability play out in the life of faith. Through an event, though having completely rational and natural explanations and without the ability of ever being verified or proved, an act of the divine is recognized.

Thus far, we have covered three key components of Bultmann's hermeneutical program, viz. myth, kerygma, and nonobjectifiability. In what follows, I will similarly outline three key components of the Zen Buddhist thought of Thich Nhat Hanh, pulling from both secondary sources about Zen Buddhism and Nhat Hanh's own works. Though similarities will no doubt arise in the mind of the reader as progress though Nhat Hanh's thought is made, I will end by pointing out the hermeneutical resemblance between these two thinkers in their respective religious traditions.

\section{Thich Nhat Hanh and the Contemporary Innovation of Zen}

Thich Nhat Hanh, born in Vietnam in 1926, rose to popularity and fame due to his involvement in the Vietnam War. Nhat Hanh advocated what he called the Third Way, "siding with neither the North nor South Vietnamese side, but with life." After the war, Nhat Hanh took up residence in France where he has "created and taught a form of Buddhist spirituality and social activism that has appealed to people all over the world" (King 2018, 480). Nhat Hanh's Buddhism is a blend of traditional Buddhism tenets, as well as more innovative teachings which have been produced out of his life and thought. The first of these tenets belongs to both: interbeing.

Interbeing, at its most fundamental, is a way-of-seeing which asserts that there is no such thing as an "individual." Rather, everything is ever interconnected and in relationship with everything else. Nhat Hanh, who actually established an Order of Interbeing in 1966, is worth quoting at length here:

When we look into the heart of a flower, we see clouds, sunshine, minerals, time, the earth, and everything else in the cosmos in it. Without clouds, there could be no rain, and there would be no flower. Without time, the flower could not bloom. In fact, the flower is made entirely of non-flower elements; it has no independent, individual existence. It "inter-is" with everything else in the universe (Nhat Hanh 2007, 213).

On the website of Nhat Hanh's Order of Interbeing, it addresses interbeing thus: "Interbeing is not a theory; it is a reality that can be directly experienced by each of us at any moment in our daily 
lives" (www.orderofinterbeing.com). And this "reality" is not only contained to the world of nature, but also extends to the realm of systems, religion, philosophy, etc. Nhat Hanh says as much about Buddhism and Christianity, respectively. We will come back to this in the next section.

The second tenet we will touch on here is that of "engaged Buddhism," or the priority of praxis and ethical action in the Zen tradition. With King:

Engaged Buddhism is a contemporary form of Buddhism found throughout the Buddhist world...[It] may be defined as those forms of Buddhism that intentionally and nonviolently engage with the social, political, economic, and environmental issues of society and the world on the basis of and as an expression of Buddhist beliefs, values, concepts, world view, and practices (King 2018, 480).

This type of Buddhist spirituality goes against the popular understanding that Buddhism is about withdrawing from the world in order to achieve peace and mindfulness.

Nhat Hanh $(2007,214)$ defines mindfulness as "the energy to be here and to witness deeply everything that happens in the present moment, aware of what is going on within and without." Mindfulness training has deep roots in the Zen Buddhist tradition and is closely tied to moral and ethical action. Christopher Queen $(2018,512-513)$ points out the danger of practicing mindfulness divorced from the expectation of ethical action in the world: "Mindfulness training in the absence of morality may blind practitioners to the social, institutional, economic, and tactical conditions that have precipitated or exacerbated the stress and suffering they have turned to meditation to escape."

As is likely apparent by now, the emphasis in engaged Buddhism lies heavily on praxis and experience rather than dogmas. Though there are, indeed, tenets of Zen Buddhism and engaged Buddhism, these tenets must continually be cultivated, practiced, and experience. These tenets are the ways one may formulate and speak of the experiences one experiences through the practice and ethics of mindfulness.

Last, we will address the nontheistic tendencies of Zen Buddhism. Rita Gross $(2014,468)$ explains this well in her essay on Buddhism: "Because Buddhism is a non-theistic religion, its concepts of ultimate reality do not include the kind of deity familiar from most religions. Instead, one does find anthropomorphic representations of key Buddhist virtues, such as wisdom and compassion, but they have no independent, eternal existence."

Nhat Hanh (1999) says as much when he states that "You cannot consider God as one of the things that operates in the realm of phenomena...God is not a being in the phenomenal world." For Buddhism, there is indeed a category which operates similarly to the category of "God" in other religious traditions. However, this category is not occupied by a god as such, i.e. by a "theistically conceived Supreme Being." Instead, “Zen Buddhism's emphasis on attaining states of mind that subvert the subject-object structure of everyday rationality is particularly appealing to those who seek a 'context of existential and cosmic meaning' while retaining a suspicious stance toward any and all forms of supernatural mysticism" (Fuller 2017, 579-581). In other words, Buddhism allows its practitioners to create meaning in a seemingly meaningless world while disposing of any and all concerns of a metaphysically divine punisher or rewarder.

Above, we have briefly outlined three basic tenets of Zen Buddhism and Nhat Hanh's particular brand of Zen Buddhism. In the next section, I will bring together one of the tenets of Nhat Hanh's Buddhism and one of the tenets of Bultmann's hermeneutical program and discuss their differences and, perhaps more importantly, their similarities. My hope is that this will not only bring into dialogue two major religious traditions on how they understand their faiths, but will also lend credibility to Bultmann's program by showing that, despite religious, cultural, linguistic, et al. differences, the category for the divine in each's thought functions relatively the same way.

\section{Bultmann and Nhat Hanh in Conversation}

In the above sections, I have approached the elements of both thinkers' thought in the order I would like to address them here. Thus, the first element I discuss for Bultmann is that of myth, and the first 
I discuss for Nhat Hanh is that of interbeing. This is, arguably, the easiest connection to make between the two thinkers. For Bultmann, myth is the objectifiable garments wrapped around the kerygma in order for the hearer to make sense of it in their world and current time-and-place in history.

Thus, Christianity was birthed out of a time-and-place in history which held to a notion of a three-tiered universe, angels and demons as explanations for sickness, divine reward and punishment as an explanation for the rich and the poor, etc. So, when the kerygma came upon the early church in the proclaimed word of Jesus Christ crucified and risen, they used these existing notions, and others, to tease out what exactly was going on within them kerygmatically. With this being so, one might say, along with Nhat Hanh, that Christianity is composed of completely nonChristian elements.

There is nothing distinctly "Christian" about these ancient methods of meaning-making in the face of human limitation and frailty. They are merely the then-current modes of thinking through the existential perplexities common to every human being. Nhat Hanh $(2007,11)$ extends his notion of interbeing to religion as well: "Just as a flower is made of only non-flower elements, Buddhism is made only of non-Buddhist elements....and Christianity is made of non-Christian elements...We have different roots, traditions, and ways of seeing, but we share the common qualities of love, understanding, and acceptance." According to Bultmann's program of demythologizing, we can already begin to see how Christianity and Buddhism are speaking about the same "other" or "divine," only conveyed through different concepts and philosophical systems.

Second, with Bultmann, we discussed the question of what exactly is "clothed" by myth. The answer to that question is, of course, the kerygma. The kerygma is that which we encounter in the proclaimed word of Jesus Christ crucified and risen; the word which makes us known of the forgiveness of our past and opens us fully to the future. This kerygma is inherently actualistic in that it can never be completely objectified, but only formulated in the form of dogmas. However, for Bultmann, these dogmas which we express from a stance of faith, only serve to help us as we work to bring our lives into line with the kerygmatic event of encounter.

This finds a parallel in the nondogmatic, actualistic nature of Zen and its sub-tradition of engaged Buddhism. Just as in these Buddhist traditions, mindfulness is never something which can be demonstrated or objectified in an absolute way, but must be renewed in every moment of existence so as to adapt to every situation and circumstance anew, the kerygma functions the same way in Bultmann's thought vis-à-vis the event of faith. Faith, ultimately, is never something that we own. It is never a thing we possess, but is an event which is thrust upon us. Our responsibility, though, is to be ever prepared for that event by renewing our belief in Jesus every moment.

Lastly, we addressed Bultmann's and the Dialectical School's notion of nonobjectifiability. We said that this notion begins upon the assertion that God is not a part of the ontological inventory. Not only is this the strongest antithesis to natural theology, but is also the ultimate separation of modern believers from ancient believers. Whereas our religious ancestors believed in a personal, relational deity who existed metaphysically in the sky, nonobjectifiability does away with any and all concepts of the like. No one can say as much today without objectifying God and resting on the laurels of ancient cosmology. Rather, God is wholly transcendent or wholly other in a way that we can never speak of God in Godself apart from God's action in the world via the event of faith.

This opposition to classical theism is the same opposition present within Buddhism and its nontheistic tendencies. The category of the divine, where Christians place 'God,' is the same category where, for Buddhists, mindfulness exists. The divine, the "wholly other", in this understanding, is that which affords meaning to and orders the life of the practitioner. One might even venture to claim that there have been very few true "atheists" or "nontheists" in the history of religious and philosophical thought because there are likely very few people who would readily admit that there is no objective meaning in life alongside the notion that there is also absolutely no way to subjectively create meaning in life. The theism that Nhat Hanh and Zen Buddhism are opposed to is the same theism that Bultmann and dialectical theology are opposed to. Both are 
interested in subjectively creating meaning in a meaningless world; they both merely have, by accident of birth, been conditioned to do so through different linguistic, philosophical, and religious systems.

\section{Conclusion}

In such a time of religious ignorance, there is a need for compassionate and loving dialogue amongst different religious traditions. And with Nhat Hanh, we should be willing to say that "In a true dialogue, both sides are willing to change" (Nhat Hanh 2007, 9). Christians have much to learn from our Buddhist brothers and sisters. They are fellow travelers in the religious wilderness just like us. To assume they are wrong because they describe their encounters with the divine in a different way, using different scriptures and language, is to assume that they are not only less intelligent, but that they are less than human.

The work of Bultmann can help us at this juncture in history by helping us make sense of and affirm the religious traditions outside our own without robbing them of the truth and meaning they find in it. Religious pluralism need not be a problem if we merely affirm and love one another despite differences because our differences are not things to fear, but to celebrate. It seems only fitting to end with the words of Nhat Hanh on this very problem:

We don't want say the Buddhism is a kind of Christianity and Christianity is a kind of Buddhism. A mango cannot be an orange. I cannot accept the fact that a mango is an orange. They are two different things. We have to preserve differences. It is nice to have differences... But when you look deeply into the mango and into the orange, you see that although they are different, they are both fruit... At first you see the differences between the orange and the mango. But if you look a little deeper you discover many things in common (Nhat Hanh 1999, 17).

\section{References}

Bultmann, Rudolf. 1958. Jesus Christ and Mythology. New York: Charles Scribner's Sons.

Bultmann, Rudolf. 1984. New Testament and Mythology and Other Basic Writings. Trans. Schubert M. Ogden. Philadelphia: Fortress Press.

Bultmann, Rudolf. 1955. Theology of the New Testament, vols. 1 \& 2. New York: Charles Scribner's Sons.

Congdon, David. 2015a. The Mission of Demythologizing: Rudolf Bultmann's Dialectical Theology.. Minneapolis: Fortress Press.

Congdon, David. 2015b. Rudolf Bultmann: A Companion to His Theology. Eugene, OR: Cascade Books.

Frei, Hans. 1956. The Doctrine of Revelation in the Thought of Karl Barth, 1909-1922: The Nature of Barth's Break with Liberalism. Ann Arbor, MI: UMI.

Fuller, Robert C. 2017. "Secular Spirituality.” The Oxford Handbook of Secularism. Eds. Phil Zuckerman and John R Shook. Oxford: OUP.

Gross, Rita M. 2014. "Buddhism." The Oxford Handbook of Theology, Sexuality, and Gender. Ed. Adrian Thatcher. Oxford: OUP.

Hardwick, Charley D. 1996. Events of Grace: Naturalism, Existentialism, and Theology. New York: Cambridge University Press.

Hunsinger, George. 1991. How to Read Karl Barth: The Shape of His Theology. Oxford: OUP.

Jenson, Robert. 1963. Alpha and Omega: A Study in the Theology of Karl Barth. New York: Nelson.

Kay, James F. 1994. Christus Praesens: A Reconsideration of Rudolf Bultmann's Christology. Grand Rapids, MI: Eerdmans.

King, Sallie B. 2018. "The Ethics of Engaged Buddhism in Asia.” The Oxford Handbook of Buddhist Ethics. Ed. Daniel Cozart and James Mark Shields. Oxford: OUP.

McCormack, Bruce. 1997. Karl Barth's Critically Realistic Dialectical Theology: Its Genesis and Development, 19091936. Oxford: OUP.

Nhat Hanh, Thich. 2007. Living Buddha, Living Christ, 2nd ed. New York: Riverhead Books.

Nhat Hanh, Thich. 1999. Going Home: Jesus and Buddha as Brothers. New York: Riverhead Books.

Order of Interbeing. n.d. "The Fourteen Mindfulness Trainings of the Order of Interbeing." Accessed March 7, 2018. https://orderofinterbeing.org/for-the-aspirant/fourteen-mindfulness-trainings/.

Queen, Christopher. 2018. "The Ethics of Engaged Buddhism in the West." The Oxford Handbook of Buddhist Ethics. Ed. Daniel Cozart and James Mark Shields. Oxford: OUP. 